\title{
Neuroaesthetical Changes in Sculpture: The Case of Yannoulis Halepas (1851-1938)
}

\author{
Maria Ioanna Stefanou Ulf Ziemann \\ Department of Neurology and Stroke, and Hertie-Institute for Clinical Brain Research, Eberhard-Karls University of \\ Tübingen, Tübingen, Germany
}

\section{Keywords}

Neuroaesthetics $\cdot$ Sculpture $\cdot$ Schizoaffective disorder ·

Art · Halepas

\begin{abstract}
The theoretical conceptualization of artistic ingenuity and creativity, as reflections of the highest-level cognitive functions in the human brain, has recently evolved from a purely philosophical pursuit to a compelling neuroscientific undertaking. Changes in artistic style have been extensively studied in association with brain dysfunction in the presence of neurological and psychiatric diseases in famous artists. This paper presents the case of Yannoulis Halepas (1851-1938), who is widely regarded as the most influential sculptor of modern Greek art. At the age of 27, already at the peak of his fame, Halepas abruptly abandoned the sculpture world after developing schizoaffective disorder, only to resurge onto the art scene after an almost 40-year-long hiatus with a fundamentally reformed artistic style. Two distinct periods have preoccupied art critics: Halepas's early premorbid years (1870-1878), which were imbued with the principles of neoclassicism, and the later postmorbid years (1918-1938), which mark the artist's transcendence to expressionism and contemporary art. From a neuroaesthetical perspective, the
\end{abstract}

extensive and multifaceted oeuvre that Halepas produced in his lifetime allows a close study of his artistic development throughout and beyond mental disease. In addition, his lifework is a unique account in the history of art of the struggle of artistic genius with the limits of the rational mind and its conscious reality.

(c) 2020 S. Karger AG, Basel

\section{Introduction}

The theoretical conceptualization of creativity and artistic ingenuity, as reflections of the highest-level cognitive functions in the human brain, has recently evolved from a purely philosophical pursuit to a compelling neuroscientific undertaking. Neurobiological theories of aesthetics have been put forth to construe the biological foundations of visual art and aesthetic perception [1]. According to the recently established theories of neuroaesthetics [2, 3], art is conceptualized as an extension of human brain function in its search for essentials [4].

From a very distinct perspective, artistic production has been extensively studied in association with brain dysfunction related to neurological and psychiatric dis-

\section{KARGER}

(c) 2020 S. Karger AG, Basel

karger@karger.com

www.karger.com/ene
Maria-Ioanna Stefanou

Department of Neurology and Stroke

Hertie-Institute for Clinical Brain Research, Eberhard-Karls University of Tübingen

Hoppe-Seyler-Strasse 3, DE-72076 Tübingen (Germany)

E-Mail maria-ioanna.stefanou@med.uni-tuebingen.de 


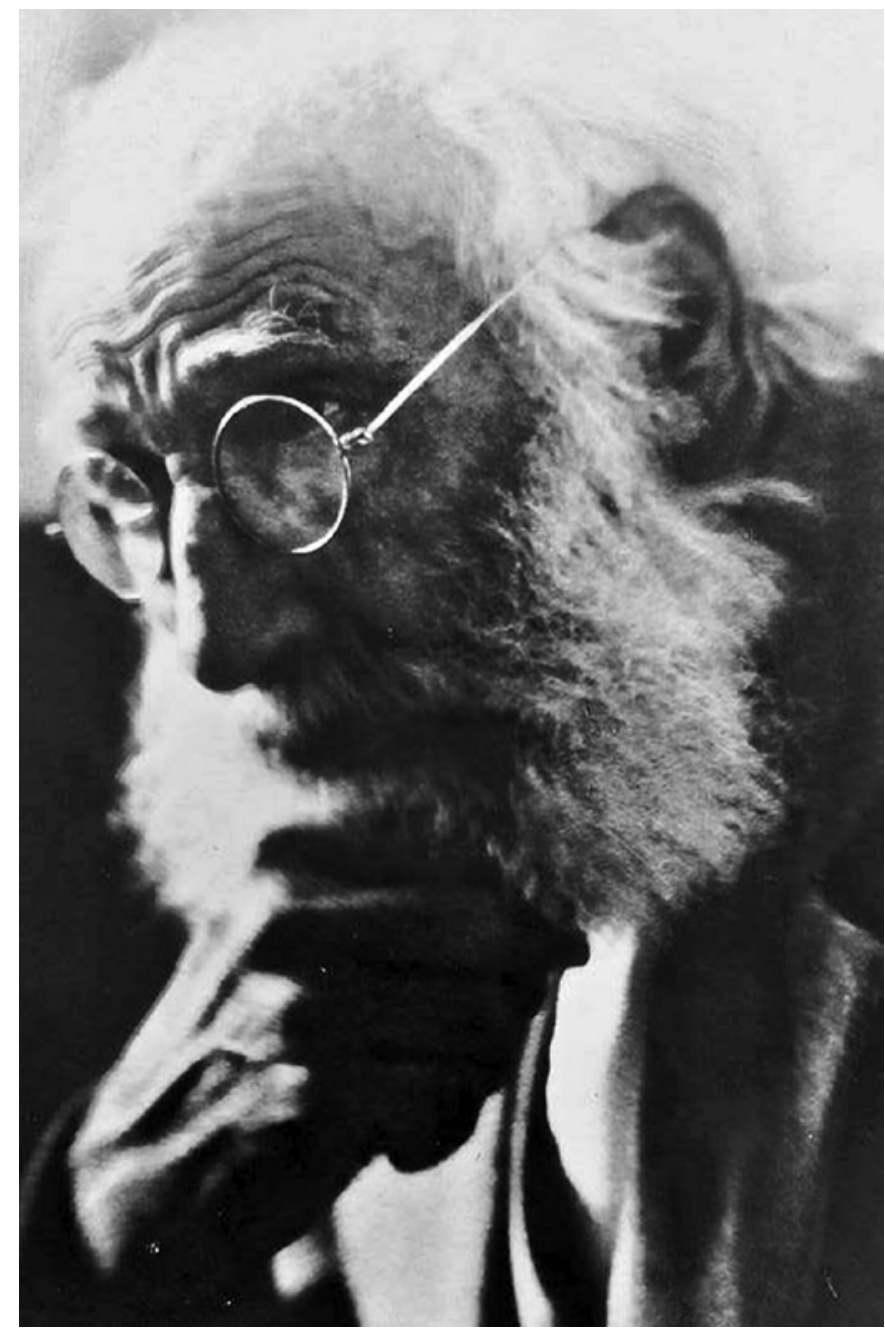

Fig. 1. The sculptor Yannoulis Halepas (1851-1938; public domain).

eases. As changes in artistic style are entrenched in the works of famous artists affected by neuropsychiatric disorders, the study of their lifework trajectories uncovers the fundamental aspects of the impact of the neuropsychiatric disease processes on artistic creativity [5-7]. Undeniably, the view that genius and insanity are entwined remains to date one of the most alluring philosophical and neuroscientific debates [8-10].

This paper is concerned with the case of Yannoulis Halepas (1851-1938; Fig. 1), who is widely regarded as the most influential sculptor of modern Greek art. At age 27, already at the peak of his fame, Halepas abruptly abandoned the art world after developing schizoaffective disorder, only to reemerge in sculpture after an almost 40-year-long hiatus with a fundamentally re- formed artistic style. Two distinct periods have preoccupied art critics: Halepas's early premorbid years (1870-1878), which were imbued with the principles of neoclassicism, and the later postmorbid years (19181938), which marked the artist's transcendence to expressionism and contemporary art. The extensive and multifaceted oeuvre that Halepas produced in his lifetime allows a close study of his artistic development throughout and beyond mental disease. In addition, his lifework trajectory reflects uniquely the struggle of artistic genius with the limits of the rational mind and its conscious reality.

\section{Life and Work}

Yannoulis Halepas was born in 1851 to a family of marble carvers in Pyrgos, on the island of Tinos. He was the eldest of the 5 children of Ioannis Halepas, a marble sculptor, who had created one of the most successful marble-carving companies during the second half of the 19th century, with branches in Tinos, Bucharest, Smyrna and Piraeus [11]. From an early age, Yannoulis Halepas showed a keen interest in sculpture, and defying his father's pressures to become a merchant, he decided to devote himself to art. Between 1869 and 1872, he studied at the School of Arts in Athens, under the accredited Greek neoclassical sculptor Leonidas Drosis (1834-1882) [12]. In 1873, he received a scholarship from the Panhellenic Holy Foundation of Evangelistria of Tinos and moved to Munich, where he enrolled in the Munich Academy of Fine Arts and apprenticed under the esteemed German neoclassical sculptor Max von Widnmann (1812-1895). In Munich, he rapidly became one of the most promising sculptors of his generation, praised by critics after his award-winning debut in art exhibitions, with contributions including his masterpiece, "Satyr Playing With Eros" (1877; Fig. 2). After an unexpected termination of his scholarship, Halepas faced extraordinary financial difficulties in Munich. Despite his outstanding academic performance and an appeal of German scholars (including the Director of the Munich Academy of Fine Arts, Karl von Piloty [1826-1886] [12]) to the Greek Ministry of Education and Culture for extension of his scholarship, Halepas lacked the financial resources to remain in $\mathrm{Mu}$ nich and was forced to return to Greece. Although no medical accounts exist regarding the exact onset of his mental disease, biographical sources suggest that Halepas presented the first symptoms of depression during this period [11]. 


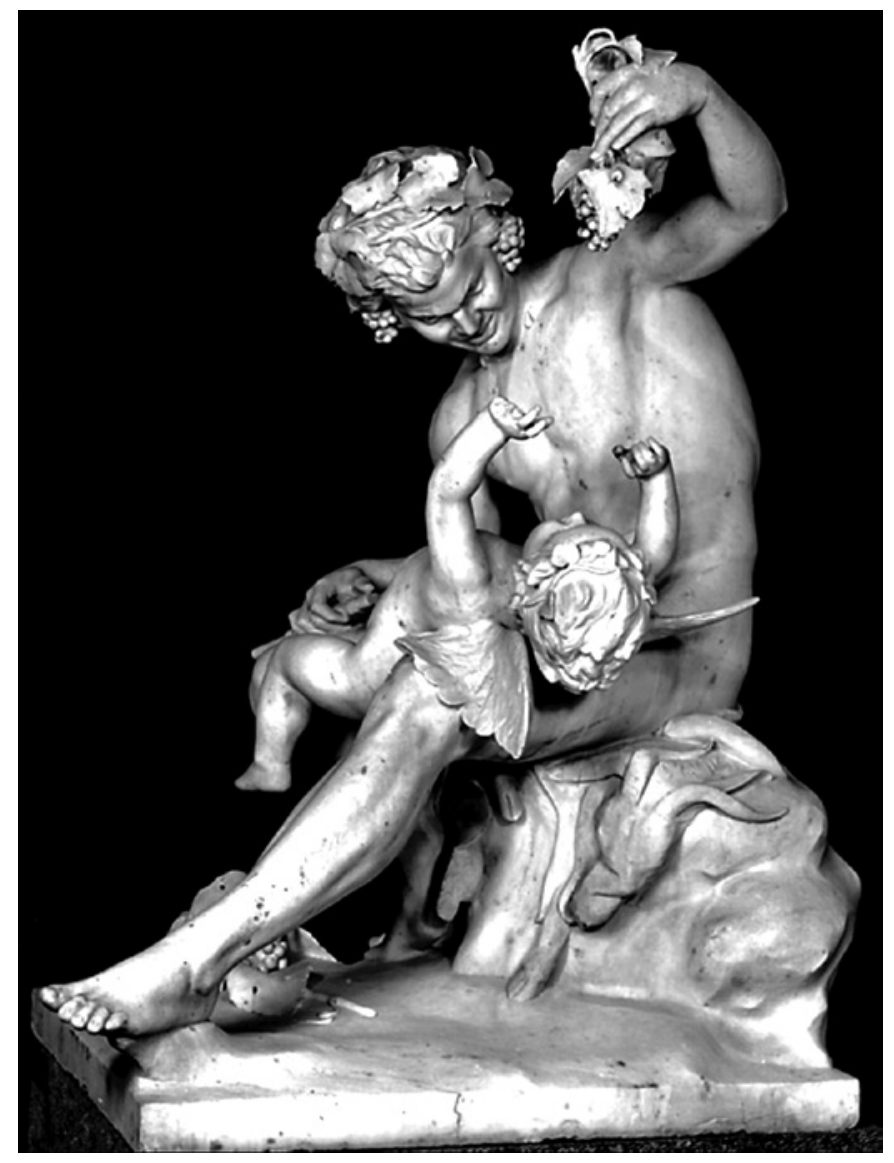

Fig. 2. "Satyr Playing with Eros" (1877), National Glyptotheque, Athens (public domain).

In 1876, Halepas returned to Athens, where his fame in artistic circles preceded him. Shortly thereafter, he created one of his most renowned statues, the "Reclining Woman" (1877; Fig. 3a), a recumbent marble effigy, which was installed in the First Cemetery of Athens. Over the ensuing months, after experiencing a romantic rejection, Halepas's mental state declined rapidly. According to his biographers' accounts, he withdrew from public life and barricaded himself in his studio, working exhaustively and presenting with an unprecedented irritability and aggression (symptoms that may retrospectively indicate a phase of mania or hypomania). Around this time, he began to systematically destroy the clay models in his studio with a hammer, and during the creation of his statue of "Satyr" (1878), he developed the first documented symptoms of psychosis. According to reports from his family, the sculptor began perceiving Satyr as a living creature, whose smile appeared disparaging, threatening and repulsive [11]. He would argue loudly with the statue and cry in agony, attempting to modify the Satyr's facial expression, destroying and recreating the cast several times. Throughout the year, many suicide attempts followed.

During a short visit to Italy in 1879 , Halepas reportedly visited Michelangelo's statue of David. According to his brother's account, while facing David, Halepas narrated the story of Michelangelo, who allegedly used tactile sense to explore statuary after going blind at an advanced age [13], and commented that "only sculpture can stimulate the senses even amidst darkness." Nevertheless, over the following years, amidst a prolonged phase of illusions, hallucinations and affective instability, Halepas's artistic work would cease completely.

He spent the following years of his life in Tinos, where he suffered from social exclusion and stigma, living under the strict supervision of his mother, who blamed sculpture for his insanity and destroyed everything that he created. By this time, the family business had suffered dramatic financial losses. During these years, Ioannis Halepas displayed his overflowing rancour against his sons, who had taken over the family business and led it to bankruptcy, and eventually, the family was forced to sell all the marble-carving workshops, along with a major part of their property in Tinos [11]. In 1888, Yannoulis Halepas was committed to the Mental Institution of Corfu, where he remained in complete artistic inactivity. After the death of his father, 3 years later, he was discharged from the mental asylum, in 1902, and spent another 13 years with his oppressive mother in Tinos. After her death, in 1916, Halepas's mental state improved markedly, and after a protracted phase of artistic lethargy, he started working again, albeit with insufficient means, with a completely reformed artistic style [14].

He soon re-captivated the interest of critics and resurged onto the art scene with a massive body of work, which is characterized by the elements of expressionism and symbolical references and stands in striking contrast to his early premorbid artwork. Important sculptures of this period include the "Secret" (1927), "Oedipus and Antigone" (1930), "Resting" (1931), "The Tale of Beauty" (1932), "Medea" (1933), and "Thought" (1933). At that time, eminent personalities of the art world, including Thomas Thomopoulos (1873-1937), an accredited Greek sculptor and professor at the School of Arts in Athens, and Zacharias Papantoniou (1877-1940), the director of the National Gallery in Athens, visited him in Tinos. In 1925, a retrospective exhibition of Halepas's work was held in Athens, and in 1927, he received the Fine Arts 


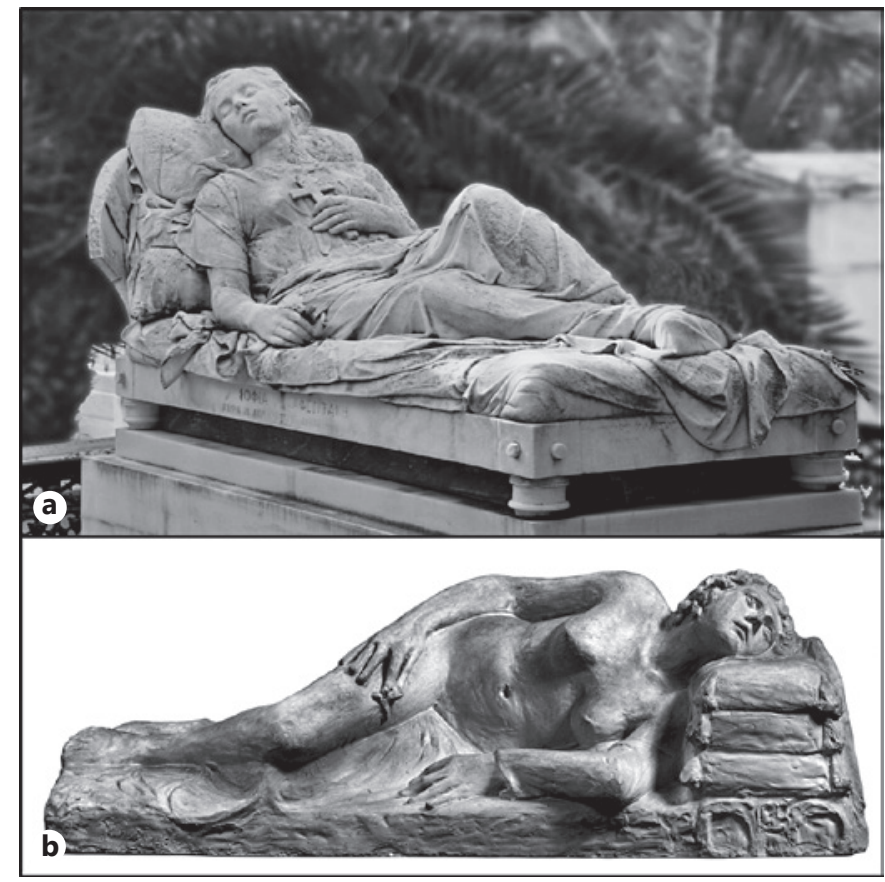

Fig. 3. a "Reclining Woman" (1877), First Cemetery of Athens. b "Resting" (1931), National Glyptotheque, Athens (public domain).

Academy's "Award for Excellence in Arts and Letters" [15]. In 1930, Halepas moved to Athens, where he set up a studio and continued sculpturing until the end of his life, in 1938. He never married or had children, but spent the last years of his life in Athens with the family of his niece, who inspired him to create one of his latest sculptures "Oedipus and Antigone" (1930) [12]. To date, Halepas is considered the most influential sculptor of modern Greek art, whose artistic evolution through his arduous inner journey intriguingly coincides with the evolution of European art movements (i.e., from neoclassicism to expressionism) at the beginning of the 20th century [16].

\section{Process of Artistic Change from a Neuroaesthetical Perspective}

\section{Nature of Halepas's Illness}

Since there appear to be no medical records regarding Halepas's psychiatric history, the diagnosis of schizoaffective disorder can only be reconstructed from accounts given by his biographers. The biographical evidence depicts symptoms of paranoid psychosis, expressed in visual and auditory hallucinations and delusions of reference (e.g., perceiving the "Satyr" as living creature laughing at him), alongside affective symptoms, including depressive and (hypo)manic episodes. In assessing Halepas's clinical case history, it is thus justified to infer, in line with the current diagnostic criteria of mental disorders [17], the diagnosis of a schizoaffective disease. Unsurprisingly, several studies have proposed a positive link between artistic creativity and mental disease, and particularly in patients with bipolar and schizoaffective disorders [5-10, 18]. Possibly, in Halepas's case, stressful experiences and emotional conflicts (e.g., during his studies in Munich after the withdrawal of his scholarship, and later, following a romantic rejection) may have precipitated the manifestation of schizoaffective disorder during a phase of intensified artistic production, which was also at a typical age for disease onset [19]. From a psychoanalytical angle, although a direct association between the oppressive behaviour of his mother and the development of a predisposed, fragile psychological profile seems almost simplistic, it is certainly noteworthy that immediately after her death, Halepas's mental state improved dramatically. At this time, he also resumed artistic work, which was frequently related to the myth of Medea (Fig. 4).

\section{Halepas's Early Premorbid Period (1870-1878)}

Mythological and symbolic references can from an early stage be detected in Halepas's work. In his statue of "Satyr Playing with Eros" (1877; Fig. 2), from his early artistic period, he represents the young Eros being held in a playful manner in the arms of the Satyr. Halepas presents the Satyr as an adolescent man, whose dual nature is barely recognizable by the pointed ears, short tail at the base of the spine, and 2 small horns on the forehead [15]. Although at first glance, the work seems to portray a joyful scene, imbued with innocence and insouciance, upon closer inspection, it becomes apparent that the Satyr's grin is mirthless and his expression is cruel. It is in vain that little Eros is trying to reach for the grapes [15]. According to art historians, this work reflects for the first time the sculptor's relationship with his father, who had early on opposed his son's artistic vocation. Ironically, the creation of "Satyr" is considered to have been catalytic for the manifestation of Halepas's mental disease. Between 1918 and 1936, he would create 11 more works on the theme of Satyr and Eros in clay or plaster, allegedly trying to liberate himself from the tyrannical father figure.

Stylistically, the early period (1870-1878) of Halepas is characterized by neoclassical elements and an em- 


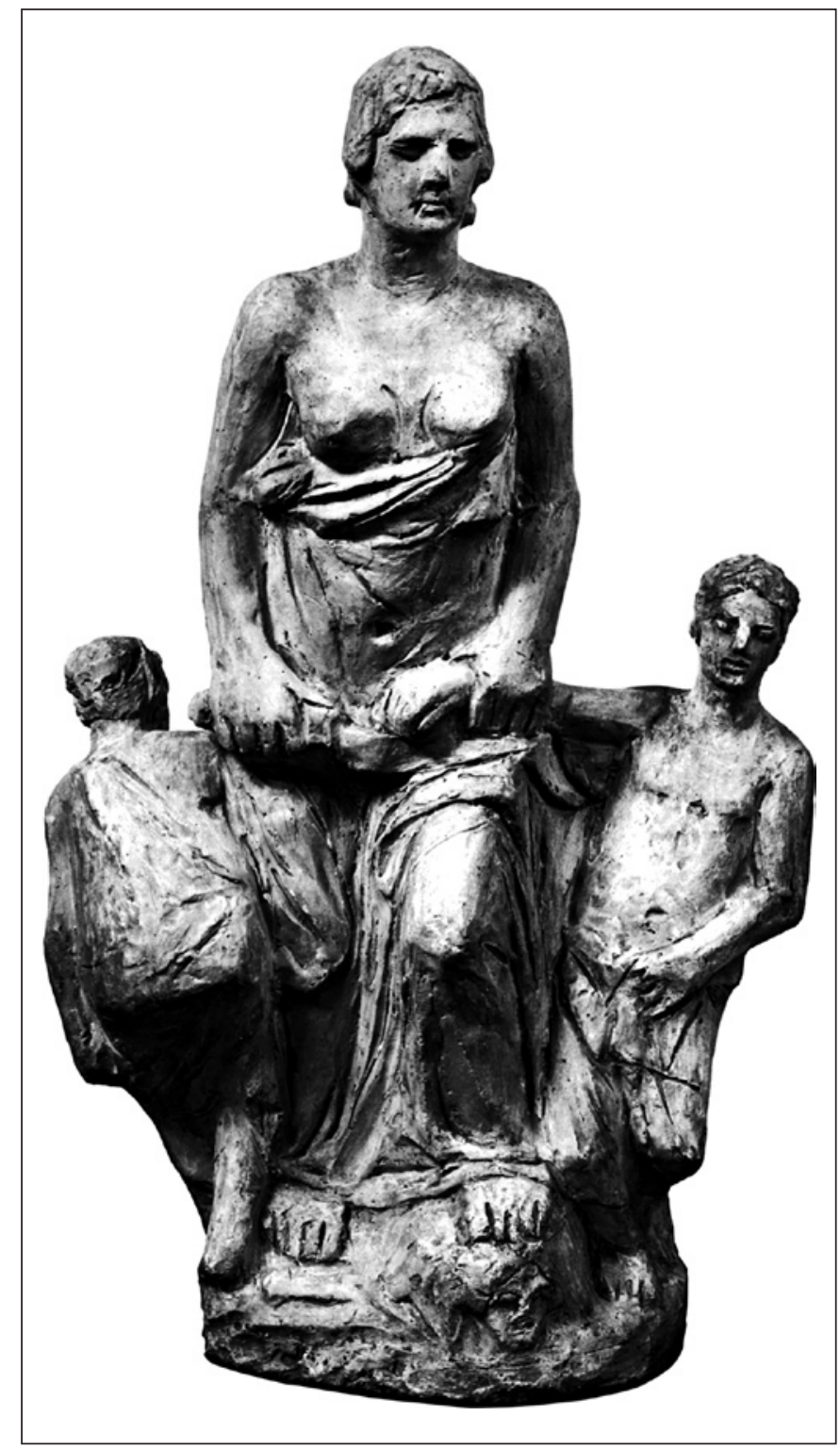

Fig. 4. "Medea III" (1933), National Glyptotheque, Athens (public domain).

phasis on technical accuracy, which was aligned with the contemporary academic standards. His early sculptures display a skilled level of control, with veristic representations, which express corporeality and naturalistic movement. In "Satyr Playing with Eros" (Fig. 2), the figures are adjoined in an open, multiaxial composition, where facial expressions alter through the interplay of light and shadow and change depending on the angle from which the statue is viewed. In "Reclining Woman" (1877; Fig. 3a), he creates a recumbent effigy, using firm lines and contours to capture the movement of the woman's clothing, displaying it in contrast to the stillness of the human body. Contextually, the technical mastery subserves, in this regard, the sculptor's goal to elicit emotional response. During this early phase, Halepas created mostly on marble, illuminating an aesthetic reminiscent of Hellenistic prototypes, with persistence in representational nuances and accuracy in perspective.

\section{Halepas's Late Postmorbid Period (1918-1938)}

By the time Halepas resurfaces on the artistic scene, in 1918, the artistic milieu had been fundamentally reformed through the works of distinguished contemporary European artists, including Auguste Rodin (18401917), Henri Matisse (1869-1954) and Raymond Duchamp-Villon (1876-1918) [16]. Sculpture has already departed from neoclassical standards to novel art tendencies, including expressionism, impressionism and cubism. These revolutionary art movements conceptualize, for the first time, art as an intuitive cognitive and emotional process. During his 40 -year-long hiatus of artistic oblivion, it is highly unlikely that Halepas (confined to a mental asylum and later to the remote island of Tinos) was exposed to the artistic influences of that time. Instead, it seems more plausible that after a prolonged period of inner struggle with mental disease, he underwent a fundamental transformation in his artistic consciousness that intriguingly coincided with the reappraisal of instinctive self-expression in European art. According to art historians, Halepas's postmorbid work reflects a radical change of style toward expressionism, which characterizes the whole body of his late period (1918-1938).

Although myth and symbolism remain at the centre of his thematology, stylistically Halepas's work transcends to a more abstract, less elaborate and dream-like approach. He expresses an altered emotional attitude towards sculpture, which bears references to atavism and the primitive unconscious. This apparent artistic change can be uniquely witnessed in the sculpture "Resting" (1931; Fig. 3b). Compared with his premorbid style in "Reclining Woman" (1877; Fig. 3a), "Resting" is created with less detail and nuance and less emphasis on spatial contours and anatomical exactitude; yet, the sculpture is characterized by a captivating directness, which elicits in the viewer an almost instinctual emotional response. While his art has undergone major changes in depiction of forms, in this late period of his work, the artistic theme and emotional process come into the foreground. 
Fig. 5. a "Thought” (1933), National Glyptotheque, Athens. b "Secret" (1927), National Glyptotheque, Athens (public domain).

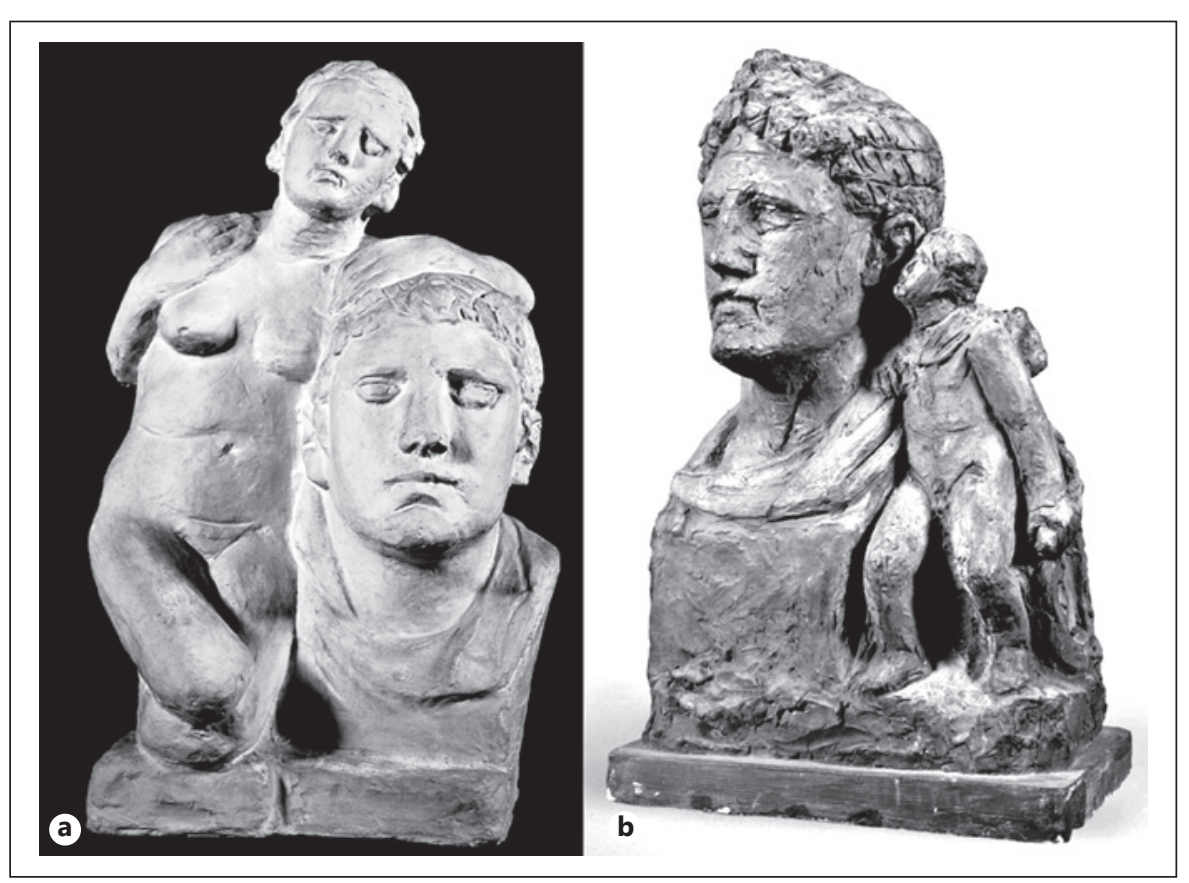

The artistic changes experienced by Halepas are certainly not unique. Other cases of artists affected by neuropsychiatric disorders have shown a coarsening of structure and a lack of anatomical exactitude in the artists' postmorbid works [20]. Moreover, a possibly decreased inhibitory control in conjunction with neuropsychiatric disease might explain the more spontaneous expression in the late work of Halepas, which results in a positive gain in expression [21]. It is also conceivable that the stylistic changes (i.e., with loss of accuracy and detail), and the incorporation of this expressive approach in a renewed artistic framework, may have been necessary for Halepas to mitigate disease-associated cognitive deficits (including impairment in executive function, memory, attention, concentration, and perceptuomotor function) [22] or to compensate for the long-term absence from technical training.

In addition to the change in genre, the confrontation of the artist with mental anguish and frailty can be observed in other postmorbid works, including the busts "Thought" (1933; Fig. 5a) and "Secret" (1927; Fig. 5b). In "Thought," the artist depicts cognitive processes in portraying the head of a man, inseparably connected with a small standing figure (i.e., the thought); but it is in "Secret" that Halepas captures in an unparalleled way the mental anguish of psychiatric disease. Here a small standing figure (i.e., the secret) is attached to the head of a man, with the figure portrayed as it leans towards

The Case of Yannoulis Halepas

(1851-1938) the man's ear whispering. In both sculptures, the smaller figures (i.e., the thought and the secret) are positioned in striking contrast to previous syntheses (e.g., the open spatial relations of figures in "Satyr Playing with Eros") and appear in close proximity to the head busts, almost as being fused and embodied. Intriguingly, recent research from cognitive neuroscience has indicated that illusory perceptions in patients with psychiatric disorders are characterized by altered perception of embodiment and have been linked to changes in pictorial depictions in self-portraiture [23, 24]. Furthermore, taking Halepas's long history of auditory and visual hallucinations into account, in "Secret" we witness a bold, open confrontation of the sculptor with the subject of mental illness. In uniquely capturing the struggle between cognition and the limits of perceptive and conscious reality in the human mind, "Secret" may be perceived as one of the most inspiring artworks in the field of neurology of art.

\section{Synopsis and Concluding Remarks}

The extensive and multifaceted oeuvre (consisting of almost 150 preserved artworks) that Halepas produced in his lifetime allows a comprehensive theoretical analysis regarding the interplay of neuropsychiatric disease processes, aesthetic consciousness and artistic creativity. 
Although art critics have commonly postulated that the aesthetic and artistic metamorphosis of the sculptor reflected in his postmorbid work pertained to neuropsychological changes related to psychiatric disease $[12,15]$, this view should be regarded as debatable. In the case of Halepas, like in similar cases of famous artists affected by neuropsychiatric disorders [23], although artistic change coincides with the occurrence of disease, it is impossible to establish a direct causal association between disease processes and change in artistic style. Further neuroscientific research is warranted to establish the neurobiological underpinnings of aesthetic consciousness and artistic creativity and their alteration in the presence of neuropsychiatric disease.

Moreover, the lifework trajectory of Yannoulis Halepas (1851-1938) reflects uniquely the struggle of artistic genius with the limits of rational mind and its conscious reality. In contrast to other cases of famous sculptors, including Camille Claudel (1864-1943), whose art diminished after manifestation of a psychiatric disorder, Halepas, through his sculpture, reemerged from mental illness in a fundamentally reinvigorated art. In this regard, the case of Halepas serves as an inspiring example of the therapeutic effect of artistic creation on the course of psychiatric disease [25]. Additionally, as the late postmorbid period of Halepas is considered to have been unparalleled, paving the way for expressionism and modernism in Greece, his case is a unique historical account on how artistic talent, through resilient and conscious endeavour, overcomes the disability of mental disorder.

In conclusion, the art of Halepas reflects uniquely the inherent limitations, but also the impregnable abil- ities of the conscious human mind. To date, the research of neural correlates of artistic ingenuity and aesthetic perception remains in its infancy. Nonetheless, the fascinating, interdisciplinary field of neuroaesthetics, fostering the collaboration between art historians, critics, neuroscientists, and philosophers, facilitates today the first steps towards understanding the intricate relationship between the human brain and visual arts $[4,23]$.

\section{Acknowledgement}

The authors have no support to report.

\section{Statement of Ethics}

Not applicable.

\section{Disclosure Statement}

None of the contributing authors has any conflict of interests or financial ties to declare.

\section{Funding Sources}

The authors have no funding to report.

\section{Author Contributions}

M.I.S. created concept of the study and wrote the manuscript; U.Z. supervised and critically reviewed the manuscript.

\section{References}

1 Singh V, Shukla S, Ramachandran C, Mishra DK, Katikireddy KR, Lal I, et al. Science and Art of Cell-Based Ocular Surface Regeneration. Int Rev Cell Mol Biol. 2015;319:45106.

2 Chatterjee A. Neuroaesthetics: a coming of age story. J Cogn Neurosci. 2011 Jan;23(1): 53-62.

3 Zeki S, Ishizu T. The "Visual Shock" of Francis Bacon: an essay in neuroesthetics. Front Hum Neurosci. 2013 Dec;7:850.

4 Zeki S. Inner vision : an exploration of art and the brain. Oxford: Oxford University Press; 1999.

5 Delgado MG, Bogousslavsky J. Joan Miró and Cyclic Depression. Front Neurol Neurosci. 2018;43:1-7.
6 Carota A, Iaria G, Berney A, Bogousslavsky J. Understanding Van Gogh's Night: Bipolar Disorder. Neurological Disorders in Famous Artists. Basel: Karger; 2005. pp. 121-31.

7 Cooper B. Camille Claudel: trajectory of a psychosis. Med Humanit. 2008 Jun;34(1):259.

8 Jamison KR. Manic-depressive illness and creativity. Sci Am. 1995 Feb;272(2):62-7.

9 Andreasen NC. Creativity and mental illness: prevalence rates in writers and their first-degree relatives. Am J Psychiatry. 1987 Oct; 144(10):1288-92.

10 Waddell C. Creativity and mental illness: is there a link? Can J Psychiatry. 1998 Mar; 43(2):166-72.

11 Vanellis D, Petrou T. [Yannoulis Halepas.
The myth of modern Greeek sculpture]. Athens: Patakis; 2019.

12 Papadimitriou G. [A new concept of the psychopathology of art and the artist] [French]. Encephale. 1965;54(3):240-64.

13 Gallenga PE, Neri G, D’Anastasio R, Pettorrossi VE, Alfieri E, Capasso L. Michelangelo's eye disease. Med Hypotheses. 2012 Jun;78(6):757-9.

14 Xydis A. Greek Art in the European Context. J Mod Greek Stud. 1984;2(2):141-62.

15 National Gallery - Alexandros Soutsos Museum. Chalepas Yannoulis - Satyr Playing with Eros, 1877 [Internet]. [cited 2019 Nov9]. Available from: https://www.nationalgallery.gr/en/ sculpture-permanent-exhibition/sculpture/ the-19th-century-the-first-modern-greeksculptors/satyr-playing-with-eros.html. 
16 Hamilton GH. Painting and sculpture in Europe, 1880-1940. New Haven and London: Yale University Press; 1993.

17 Malaspina D, Owen MJ, Heckers S, Tandon R, Bustillo J, Schultz S, et al. Schizoaffective Disorder in the DSM-5. Schizophr Res. 2013 Oct; 150(1):21-5.

18 Richards RL. Relationships between creativity and psychopathology: an evaluation and interpretation of the evidence. Genet Psychol Monogr. 1981 May;103(Second half):261324.

19 Kao YC, Liu YP. Effects of age of onset on clinical characteristics in schizophrenia spec- trum disorders. BMC Psychiatry. 2010 Aug; 10(1):63.

20 Bäzner H, Hennerici MG. Lovis Corinth: integrating hemineglect and spatial distortions. Front Neurol Neurosci. 2007;22:3043.

21 Landis T. Die Linke weiss nicht, was die Rechte tut: Zur Interaktion der beiden Hirnhälften. Schweiz Med Wochenschr. 1988 Dec; 118(48):1779-88.

22 Studentkowski G, Scheele D, Calabrese P, Balkau F, Höffler J, Aubel T, et al. Cognitive impairment in patients with a schizoaffective disorder: a comparison with bipolar patients in euthymia. Eur J Med Res. 2010 Feb;15(2): 70-8.

23 Blanke O. I and me: self-portraiture in brain damage. Neurological Disorders in Famous Artists-Part 2. Basel: Karger; 2007. pp. 1429.

24 Blanke O. Perception and experience of the self in autoscopicphenomena and self-portraiture. Schweiz Arch Neurol Psychiatr. 2005;156:173-88.

25 Ruddy R, Milnes D. Art therapy for schizophrenia or schizophrenia-like illnesses. Cochrane Database Syst Rev. 2005 Oct;(4): CD003728. 